\title{
Using fractal characteristics to analyze the development of whole-rolled wheel destruction
}

\author{
Dmitry Kononov ${ }^{1, *}$, Svetlana Gubenko ${ }^{2}$, Igor Ivanov $^{1}$, and Sergey Urushev ${ }^{1}$ \\ ${ }^{1}$ Emperor Alexander I Petersburg State Transport University, 9, Moskovsky pr., Saint Petersburg, \\ 190031, Russian Federation \\ ${ }^{2}$ Department of material science the name U.N.Taran-Zhovnir, The National Metallurgical Academy \\ of Ukraine, 4 Gagarin ave., Dnipropetrovsk, 49600, Ukraine
}

\begin{abstract}
Purpose: Determination of mechanical characteristics of wheel steel by analyzing the development of destruction of solid-rolled wheels. Methods: Determination of the crack resistance of all-rolled wheels by testing samples from wheel steel for off-center tension with an edge crack, fractal parametrization of the fracture relief by processing the fracture photo using the R/S analysis method for fracture sections, which allows determining both the total fractal dimension of the fracture (the average for all sections), and in a specific area where there are changes in the fracture morphology. Construction of the dependence of the crack resistance parameter on the fractal dimension. Results: The possibility of analyzing wheel steel fractures by studying their fractal dimension is determined. A method of fractal parametrization of the wheel steel fracture relief is developed, which allows to obtain the value of the fractal dimension in different directions of crack growth. The fractal dimension of wheel steel is determined for different hardness values (after annealing and after thermal improvement). The dependence of the fractal dimension on the ductility characteristics of wheel steel is revealed: the lower the ductility characteristics (elongation, relative contraction) and, accordingly, the higher the hardness, the lower the value of the fractal dimension. The dependence of the fractal dimension on the coefficient of crack resistance of wheel steel KIC is determined, which makes it possible to predict the crack resistance of wheel steel depending on the fractal dimension of the fracture, as well as to judge the nature of the fracture - brittle, viscous or fatigue. Practical significance: The use of fractal fracture parameterization avoids time-consuming tests when determining the mechanical characteristics of wheel steel, as well as to determine the mechanical properties in the case when other methods are no longer applicable (small sample sizes).
\end{abstract}

A railway wheel, which is a structural element, undergoes a complex set of cyclic loads that change in level, frequency, and duration during operation [1].

Finding out the nature of the origin of damage to solid-rolled wheels is one of the main tasks in solving issues of their reliability and durability [2-6]. Generalization of the results

*Corresponding author: d_kononov@mail.ru 
of mass studies of destroyed wheels is of great interest, since typical breakdowns of parts in many cases make it possible to make a conclusion about the causes of damage directly by their type and develop measures to improve their reliability and durability $[5,6]$.

Fatigue cracks mainly appear in the rim part of the disk from the inside of the wheel at a distance of $40 \ldots 70 \mathrm{~mm}$ from the rim, and their places of occurrence are located at the wheels according to GOST 10791-2011 on the mechanically untreated surface of the disk.

The process of occurrence and development of fatigue cracks is two-stage. The crack is preceded by the accumulation of fatigue damage, which leads to irreversible structural changes in the material. In the early stages of cyclic deformation, the dislocation structure evolves. At the stage of fatigue crack nucleation, the periods of cyclic micro-fluidity, cyclic fluidity, cyclic hardening, and fatigue micro-crack nucleation are distinguished $[7,8]$. The accumulation of irreversible phenomena of fatigue origin is expressed in the occurrence and movement of dislocations, the formation of vacancies, grain displacement and shifts within them, loosening of the crystal lattice, etc. On the surface, in addition, oxidation, adsorption, extrusion and intrusion occur, and selective plastic deformation, which leads to changes in microgeometry. The occurrence of a fatigue crack is associated with the formation of a critical dislocation density in the local volume of the material.

The second stage of fatigue is the growth of a macroscopic fatigue crack, which ends with a brittle fracture of the part. The process of growth of the crack itself is divided into three stages. At the first transition stage, the crack length and rate of increase are small, there is no clearly defined furrowing on the surface in the zone of the focus, and the development of cracks occurs along the sliding planes. The second stage: the crack grows perpendicular to external stresses - this is the period of steady crack growth. The crack growth rate at this stage is proportional to its length. The third period occurs with a catastrophic growth of the fatigue crack and ends with a wheel break.

As a result, there is a need to use more and more advanced methods for parameterizing the analyzed fracture, which is formed at different scale levels of the ongoing destruction processes, and to identify the leading mechanisms of self-organization on this basis.

One of these new mathematical methods is fractal analysis of the surface morphology, which reflects the course of a physical phenomenon at the considered large-scale level of self-organization [9-11].

A fractal is an object that is formed at different scale levels in a self - similar way, and that has a fractional dimension. The self-similarity of such an object is estimated based on the use of fractal dimension. Using the fractal dimension, an image of the fractal is formed at each scale level through its previous scale level, which allows you to create a self-similar object with a fractional dimension.

The multi-fractal description is based on generating a measure when dividing the space covering the object under study into cells. The study of the scaling properties of the generalized correlation function (partition function) of a measure allows you to assign some statistical values to an object for quantitative characteristics of the object and comparing it with other similar objects.

The key issue of using fractal parameterization of fracture surfaces is related to establishing the relationship between the characteristics of the energy intensity of the material, which characterize, for example, the fracture viscosity $K_{1 c}$, and the fractal dimension measured in one way or another. Difficulties in establishing such a correlation are primarily due to the fact that the fractal characteristics of the fracture surface depend on the measurement scale, $\delta,[11-15]$.

The method for determining the fractal characteristics of fractures in different directions [16] was adapted for the analysis of wheel steel.

The initially analyzed section of the fracture is reproduced as a digitized photo. In a digitized photo, the minimum distance between two neighboring points that contain useful 
information is characterized by the pixel size. For a photo with relief reproduction without loss of information, for example, due to high contrast or brightness, the value of each pixel characterizes a different degree of gray color within its gradations from 0 to 255 . A set of pixels defines the image of the photo.

In turn, a pixel can be represented as a set of mini-pixels, the number of which depends on the value of the "degree of gray" and the size of the pixel - d. The size of a threedimensional mini - pixel is obtained from the size of a two-dimensional pixel $-\mathrm{d}$. As a result of this grayscale analysis, we get a set of mini-pixels that mimics the threedimensional view of the analyzed fracture.

By performing a statistical analysis of the distribution of pixels over areas of the surface with different grayscale gradation, which is an analysis of the formed image, you can get the number of mini-pixels (TDR) $-\mathrm{N}_{\mathrm{k}}$ located on the surface of the three-dimensional image of the fracture.

Statistics on the distribution of mini-pixels characterize various morphological features of the fracture surface, and the distance between pixels - the completeness of the information obtained. In this regard, it is important to note that the parameterization of the brightness and contrast level determines the accuracy of reproducing information about the implemented process of destruction development.

The next important characteristic of the resulting image is the information content (image) of the photo itself. If you change the image of a photo by changing its resolution, which is determined by the size of the pixel $r_{k}$, then the "rate" of change of the logarithm $\mathrm{N}_{\mathrm{k}}$ from the logarithm of the value $\mathrm{r}_{\mathrm{k}}$, will be a fractal dimension $\left(D_{f}\right)_{d_{\min }}^{d_{\max }}$ :

$$
\frac{N_{k}}{S}=r_{k}^{-\left(D_{f}\right)^{d_{\max }}}
$$

for the 3-dimensional case, where $2<\left(D_{f}\right)_{d_{\min }}^{d_{\max }}<3$ :

$$
\frac{N_{k}}{L}=r_{k}^{-\left(D_{f}\right)_{d_{\min }}^{d_{\max }}}
$$

for the 2-dimensional case, where $1<\left(D_{f}\right)_{d_{\min }}^{d_{\max }}<2$ :

$$
\ln \left(\frac{N_{k}}{S}\right)=-\left(D_{f}\right)_{d_{\min }}^{d_{\max }} \ln \left(r_{k}\right)
$$

where $\mathrm{k} \in[1 \ldots \mathrm{n}]$ is the number of levels of scale;

$\mathrm{r}_{\mathrm{k}}$ - value that characterizes the scale level;

$\mathrm{N}_{\mathrm{k}}$ - the number of mini-pixels on the surface;

$\left(D_{f}\right)_{d_{\min }}^{d_{\max }}-$ the fractal dimension obtained in the range of scale levels $\left(\mathrm{d}_{\min }, \mathrm{d}_{\max }\right)$;

$\mathrm{L}, \mathrm{S}$ - length and area of the analyzed photo.

The values of $d_{\min }$ and $d_{\max }$, at which the fractal dimension reaches an extreme, characterize the leading fracture mechanism that determined the formation of the dominant fracture relief parameters in this section. That is, by conducting fractal parametrization of fractures not only of railway wheels, but also of other rolling stock parts, it is possible to determine more accurately, avoiding biased estimates, both the nature of the fracture (brittle or viscous) and the parameters of crack resistance.

The crack resistance of wheel steel grade 2 GOST 10791 for further fractal parameterization of the fracture relief was evaluated by determining the critical stress intensity coefficient $\mathrm{K}_{1 \mathrm{c}}$. The tests were carried out in accordance with the requirements of GOST 25.506. 
Six samples were produced according to GOST 25.506-85, type 3 (Fig. 1) - rectangular compact samples with an edge crack for testing for off-center tension. The initiating incision was made using an electric erosion saw with a cut radius of $0.2 \mathrm{~mm}$.

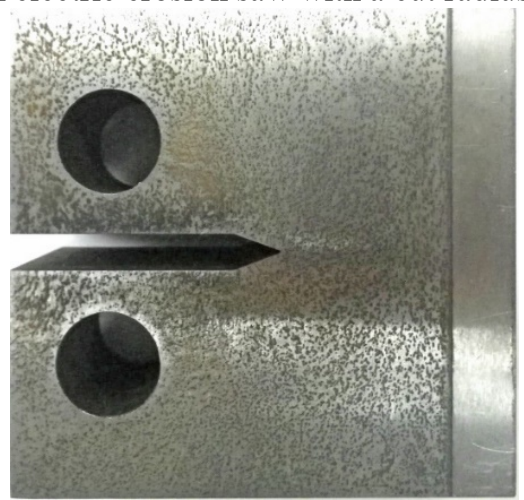

Fig. 1. Sample for testing for crack resistance

Fatigue cracks were applied in such a way that the contour of the incision was between straight lines intersecting at an angle of $20 \ldots 30^{\circ}$ at the top of the crack, its depth was not less than $1.5 \mathrm{~mm}$. The tests were carried out on the HB-250 test machine at variable tension with a cycle asymmetry coefficient of 0.1 . During the tests, load-displacement diagrams were constructed. The calculated load on the $\mathrm{P}_{\mathrm{Q}}$ sample was determined using this diagram.

Then, using the obtained values of $\mathrm{P}_{\mathrm{Q}}$, the values of the stress intensity coefficient $\mathrm{K}_{1 \mathrm{c}}$ were found:

$$
K_{1 c}=\frac{P_{Q}}{t \sqrt{b}} Y_{3}
$$

where $\mathrm{t}, \mathrm{b}$ are the geometric dimensions of the sample, $\mathrm{mm}$; $\mathrm{Y}_{3}$ - correction function,

$$
Y_{3}=13,74\left[1-3,380 \frac{l}{b}+5,572\left(\frac{l}{b}\right)^{2}\right],
$$

where 1 is the length of the initial fatigue crack, mm. It is determined by three points located at regular intervals along the thickness of the sample, excluding the side surfaces.

The calculation results are shown in table 1.

Table 1. The parameters of fracture toughness of wheel steel.

\begin{tabular}{|c|c|c|c|}
\hline $\begin{array}{c}\text { No } \\
\text { sample's }\end{array}$ & Design load $\mathbf{P}_{\mathbf{Q}}, \mathbf{k N}$ & $\begin{array}{c}\text { Initial fatigue } \\
\text { crack length I, mm }\end{array}$ & $\begin{array}{c}\text { Stress intensity } \\
\text { coefficient } \mathbf{K}_{\mathbf{1 c}}, \\
\mathbf{M P a} \cdot \mathbf{m}^{\mathbf{1} / \mathbf{2}}\end{array}$ \\
\hline 1 & 41,210 & 28,76 & 48,0 \\
\hline 2 & 36,707 & 30,08 & 48,8 \\
\hline 3 & 42,599 & 28,50 & 52,3 \\
\hline 4 & 38,683 & 30,05 & 51,8 \\
\hline 5 & 44,786 & 29,94 & 52,9 \\
\hline 6 & 40,008 & 29,85 & 52,4 \\
\hline
\end{tabular}

After determining the crack resistance indicators, the obtained fractures were analyzed to obtain a fractal dimension using the method described in [14] using R/S analysis [15].

Each of the data series obtained after processing the fracture photo was entered into the program for calculating the fractal dimension. For rice. 2 shows a General view of the data series. The abscissa axis shows the width of the sample in pixels, and the ordinate axis 
shows the value of the grayscale level. In fact, a profilogram of the fracture surface in a given direction is presented.

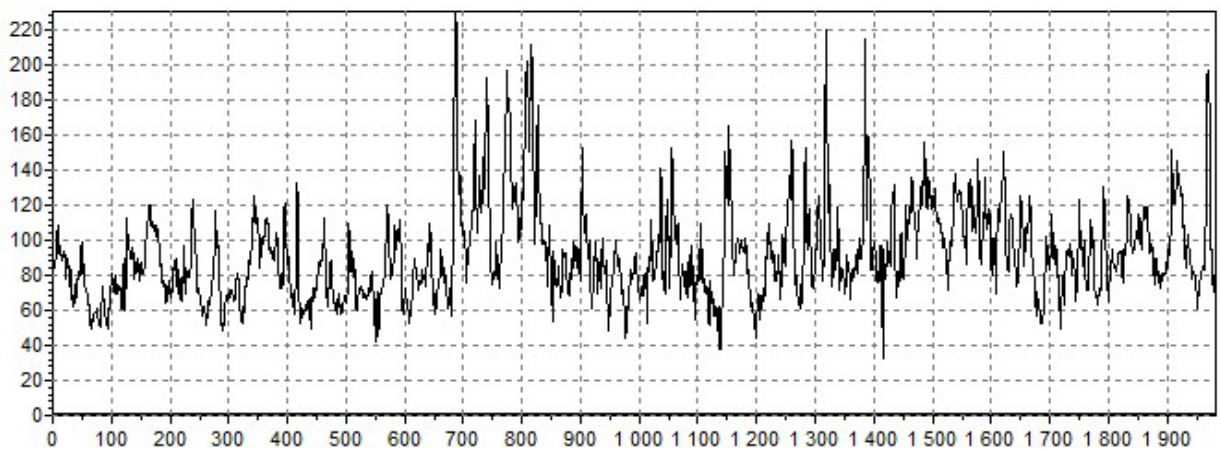

Fig. 2. Graph of the general view of a data series

After calculating the Hurst exponent, a graph of the dependence of $\lg :(\mathrm{R} S)$ on $\lg$ (t) $(\mathrm{t})$ is plotted (Fig. 3). the Tangent of the slope of the approximating straight line shows the fractal dimension.

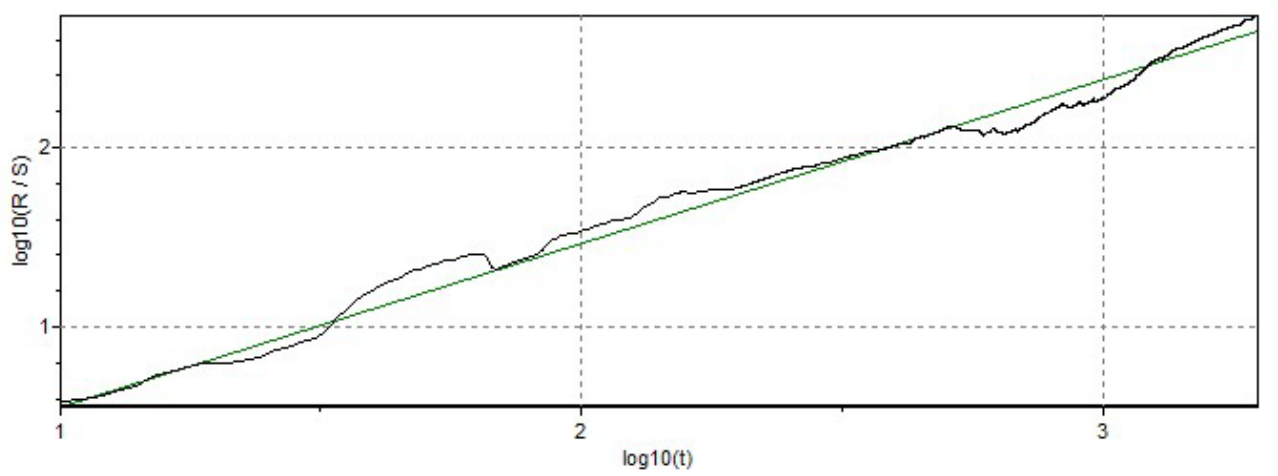

Fig. 3. The graph after the calculation of the Hurst exponent

Fractal dimension calculations were performed using cross-sections taken with an interval of 100 pixels. The average values of the fractal dimension are summarized in table 2 .

Table 2. Value of the fractal dimension.

\begin{tabular}{|c|c|c|c|c|c|c|}
\hline & \multicolumn{7}{|c|}{ Fractal dimension D of the sample № } \\
\cline { 2 - 7 } & $\mathbf{1}$ & $\mathbf{2}$ & $\mathbf{3}$ & $\mathbf{4}$ & $\mathbf{5}$ & $\mathbf{6}$ \\
\hline Average $\overline{\mathrm{D}}$ & 1,1209 & 1,1641 & 1,237612 & 1,224782 & 1,324859 & 1,254956 \\
\hline $\begin{array}{c}\text { Wed. quadr. } \\
\text { deviation } \sigma\end{array}$ & 0,069334 & 0,098627 & 0,091028 & 0,068792 & 0,113785 & 0,122960 \\
\hline
\end{tabular}

Due to the fact that the difference between the obtained values of the stress intensity coefficient $\mathrm{K}_{1 \mathrm{c}}$ is not large and does not exceed $9 \%$, it is quite difficult to establish a clear relationship between them and the fractal dimension. Meanwhile, the dependence can be traced (Fig. 4): with increasing fractal dimension, the stress intensity coefficient $\mathrm{K}_{1 \mathrm{c}}$ increases. 
The graph shows the equation of the approximating line, which allows you to predict the crack resistance of wheel steel depending on the fractal dimension of the fracture, as well as to judge the nature of the fracture - brittle, viscous or fatigue.

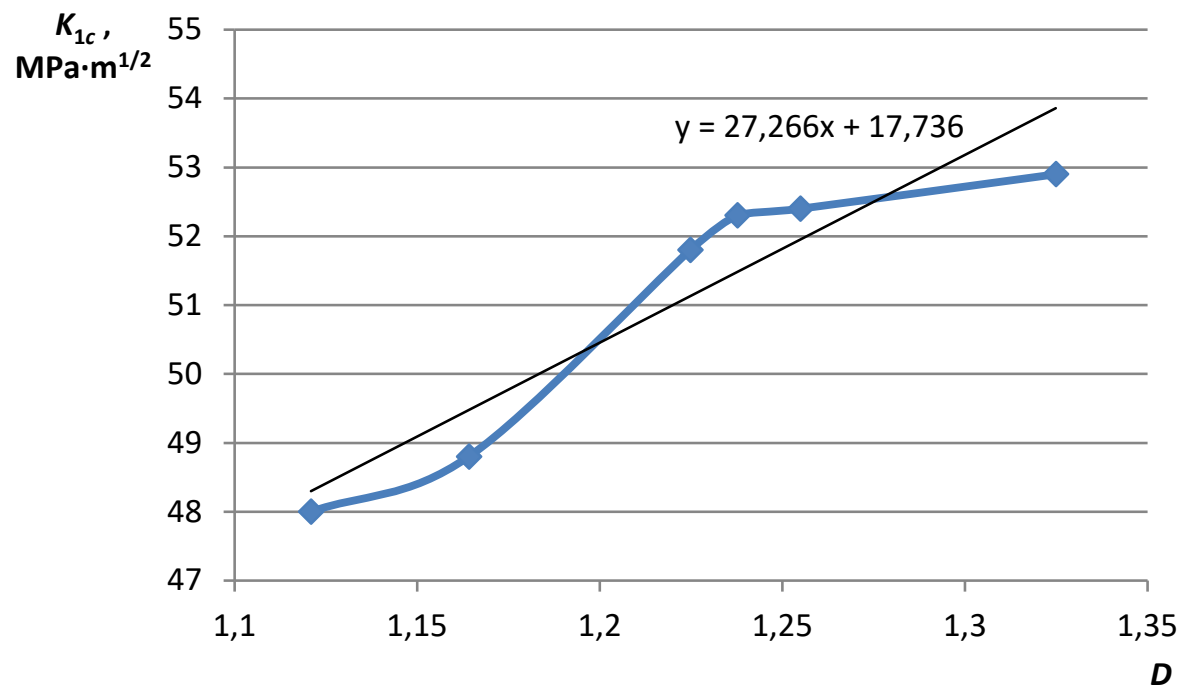

Fig. 4. Dependence of the stress intensity coefficient on the fractal dimension

Thus, the dependence of the fractal dimension on the ductility characteristics of wheel steel $\left(1<\mathrm{D}_{\mathrm{f}}<2\right)$ is revealed. The lower the plasticity characteristics (relative elongation, relative contraction) and, consequently, the higher the hardness, the lower the value of the fractal dimension: $\mathrm{D}_{\mathrm{f}} \rightarrow 1$. For high plasticity, $\mathrm{D}_{\mathrm{f}} \rightarrow 2$. Therefore, the use of fractal fracture parameterization allows you to avoid time-consuming tests when determining the mechanical characteristics of steel, as well as to determine the mechanical properties in the case when other methods are no longer applicable (small sample sizes).

\section{References}

1. A.A. Vorob'ev, Matematicheskoe modelirovanie parametrov kontakta kolesa s rel'som dlya razlichny uslovij ekspluatacii vagonov, Vestnik Instituta problem estestvennyh monopolij, v. 1 (33), pp. 34-41 (2016)

2. A.F. Bogdanov, A.M. Budyukin, I.A. Ivanov, D.A. ZHukov, S.V. Urushev, Uluchshenie svojstv metalla oboda kolesnyh par tyagovogo po-dvizhnogo sostava, Byulleten' rezul'tatov nauchnyh issledovanij, v. 1 (10), pp. 22-30 (2014)

3. A. F. Bogdanov, A.M. Budyukin, S.I. Gubenko, I.A. Ivanov, S.V. Urushev, Izmeneniya $v$ poverhnosti oboda $i$ resurs koles pri ekspluatacii, Konstrukcionnotekhnologicheskoe obespechenie nadezhnosti koles rel'sovyh ekipazhej, pp. 23-40 (2009)

4. D.P. Kononov, Povyshenie nadyozhnosti cel'nokatanyh koles, monografiya, 250 p. (2018)

5. A.A. Vorob'ev, A.M. Budyukin, V.G. Kondratenko, K.A. Merochnik, Modelirovanie dinamiki podvizhnogo sostava, Novye materialy i tekhnologii $\mathrm{v}$ mashinostroenii, v. 21, pp. 24-30 (2015)

6. A.F. Bogdanov, S.I. Gubenko, D.A. ZHukov, I.A. Ivanov, Poverhnostnyj sloj $i$ ekspluatacionnye svojstva oboda cel'nokatanogo kolesa, Konstrukcionno- 
tekhnologicheskoe obespechenie nadezhnosti koles rel'sovyh ekipazhej, p. 15-23 (2009)

7. M.YA. Gal'perin, Harakteristiki vynoslivosti metallov na dvuh stadiyah ustalostnogo razrusheniya i razlichnyh bazah ispytanij, Problemy prochnosti, v. 5, pp. 23-35 (1978)

8. M.E. Goff, O.YU. Kramarenko, Rol' nizkih napryazhenij spektra v razvitii ustalostnogo razrusheniya, Prochnost' materialov i konstrukcij, pp. 55-56 (1975)

9. C.W. Lung, Z.Q. Mu, Phus. // Rev. B., Vol. 38, №16, pp. 11781-11784 (1988)

10. G.E. Herst, Dolgosrochnaya vmestimost' vodohranilishch, Trudy Amerikanskogo obshchestva grazhdanskih inzhenerov, v. 116, pp. 770-808 (1951)

11. G.V. Vstovskij, A.G. Kolmakov, I.ZH. Bunin, Vvedenie v mul'tifraktal'nuyu parametrizaciyu struktur materialov, 115 p. (2001)

12. G.V. Vstovskij, A.A. SHanyavskij, M.A. Artamonov, A.G. Kolmakov Mul'tifraktal'naya selekciya struktur aviacionnyh titanovyh diskov kompressorov, izgotovlennyh po standartnoj tekhnologii, pri razlichnom soprotivlenii ustalostnomu razrusheniyu, II Matem. model. v sinerg. sistemah, pp. 259-261 (1999)

13. Z.Q. Mu, C.W. Lung, Theor. and Appl.Fract. Mech., v. 17, pp. 157-161 (1992)

14. O.N. Romaniv, Vyazkost' razrusheniya konstrukcionnyh stalej, Metallurgiya (1979)

15. A.YU. Ishlinskij, Ejlerovo opisanie deformirovaniya odnoj izotropnoj sredy, Prikladnye zadachi mekhaniki. Kn. 1. Mekhanika vyazkouprugih i ne vpolne uprugih tel, pp. 333-336 (1986)

16. M.A. Artamonov, Matematicheskoe modelirovanie fraktal'no-kineticheskih processov ustalostnogo razrusheniya aviacionnyh splavov s modificirovannymi poverhnostnymi sloyami, Avtoreferat diss. na soiskanie uchenoj stepeni kandidata fizikomatematicheskih nauk, - 18 p. (2006) 